\title{
THE 1938 LABOR REBELLION AND THE DEBATE OVER BIRTH CONTROL IN JAMAICA
}

On July 14, 1938, the Jamaican Daily Gleaner, the most widely read newspaper in the British colony at the time, printed a long article entitled "It Does Interest You - Birth Control” by journalist Aimee Webster. ${ }^{1}$ Webster, the London-educated daughter of wealthy Jamaican planter/politician Herbert Webster, was a well-known art critic and social reporter, serving as the "Society Editress" for the Daily Gleaner from 1938 to 1939 (ThoywellHenry 1940:192). In this article, Webster discussed the growing concern over the high birth rate of the "Jamaican poor," who "due to ignorance, produce children with reckless irresponsibility [while] upper class persons artificially regulate the coming of their children with due regard to the family's income and the health of the mother." Although she admitted that "as late as ten years ago, it might have been considered good economy for the planter and capitalist classes to know that there were large peasant families from which to obtain cheap labor," in recent years the situation had changed so that these large families were no longer seen as beneficial to Jamaica's economy or society. She attributed this shift to the rising expectations of a working class no longer satisfied with its role as cheap labor, whose "growing demands" were "stimulated not a little by the slogan of philanthropic persons and societies, crying aloud and proclaiming from posters and the press: Save the child - save the nation." The goal of her article, Webster suggested, was to uncover attitudes toward a new plan to establish birth control clinics for the working classes. ${ }^{2}$

1. For their feedback on earlier versions of this article, I would like to thank Lara Putnam and the anonymous reviewers of the $N W I G$, as well as participants at the "Does the Caribbean Have Borderlands?" workshop in Pittsburgh, the 2008 Canadian Association of Latin American and Caribbean Studies Conference in Vancouver, and the Spring 2008 Writing Seminar at the University of Pittsburgh.

2. "It Does Interest You - Birth Control," Daily Gleaner, July 14, 1938, p. 16. All articles located in The Newspaper Archives of The Jamaica Gleaner, http://gleaner.newspa-

New West Indian Guide / Nieuwe West-Indische Gids vol. 83 no. 1 \& 2 (2009):39-69 
Recognizing that medical opinion was "of utmost value," Webster sought out the views of several doctors from Kingston, the island's largest city. Although she found that all were "sympathetic, if not actually enthusiastic" about the cause, only Dr. William Edward McCulloch, a Jamaican physician, and Dr. Jai Lal Varma, an Indian-born doctor resident in Jamaica since 1933, agreed to have their views published. "Birth control," McCulloch claimed, was "an absolute necessity," particularly because Jamaica had "the highest illegitimacy birth rate in the world," leading to a situation where "already the population exceeds the economic possibilities of Jamaica to maintain." He predicted that in forty years" time, the population would be doubled if the birth rate "which is not merely unnecessarily large, but dangerously large, is not checked." Varma, who was credited by Webster for increasing interest in the topic, agreed that "birth control must be adopted for the masses if we are to check the high illegitimacy birthrate which hinders economic progress in Jamaica." To that effect, he called for the formation of a Birth Control Society by interested citizens to teach the "desirability" and methods of birth control. ${ }^{3}$

The next day, the Daily Gleaner published another full-page article by Webster on birth control, this time an interview with one of its most vocal critics, the respected Roman Catholic, Father Joseph Krim. Krim expressed his own concern over the high numbers of children born out of wedlock, which he likened to Roman Empire-style sexual overindulgence and which he also saw as contributing to a situation of moral and social decline in Jamaica. However, Krim argued that birth control was no answer to this problem; instead, it was even more "dangerous" than McCulloch's fears of growing population, was "morally degrading," and in fact was a direct attack on Jamaican family life. He suggested instead that Jamaica's moral problems be addressed through religious instruction and self-control and its economic problems through the institution of a living wage and improved housing for the working classes. ${ }^{4}$

These articles were just two of 262 birth control-related pieces published by the Daily Gleaner from June 1938 to March 1939. This included 122 articles, announcements, interviews, and editorials written by Daily Gleaner staff documenting a growing birth control campaign on the island led by a number of prominent men and women. These birth control advocates, such as Varma and McCulloch, argued that birth control was an "absolute neces-

perarcive.com/Default.aspx. In some instances, the page number assigned by the online database view finder do not correspond with the actual page numbers on the original scanned documents. In these instances I have used the page numbers on the originals.

3. "It Does Interest You - Birth Control," Daily Gleaner, July 14, 1938, p. 16.

4. "The Most Perilous Attack Ever Made upon Homelife!," Daily Gleaner, July 15, 1938, p. 16. 
sity" considering the threat posed by the overabundance of (illegitimately born) working-class children in Jamaica. Such views, however, were vehemently opposed by a number of islanders including local clergymen, religious organizations, and labor leaders, who claimed that birth control was against God's plan, threatening to Jamaica's future growth, and/or a false panacea being used to cover up the real causes of poverty and inequality on the island. All of this activity prompted a heated debate in the pages of the Gleaner, which printed 140 letters related to birth control sent to the editor from interested (largely middle- and upper-class) readers during this period, as well as in packed lectures, conferences, and sermons across the island. ${ }^{5}$ Despite the widespread controversy, on March 18, 1939 Dr. Varma saw his wish realized with the creation of the first-ever Jamaican Birth Control League, ${ }^{6}$ which opened its first clinic in August 1939.7

How can we explain the explosion in public interest, controversy, and action surrounding birth control during these ten months? As Webster recognized, it was driven in part by the activism of doctors such as Varma, as well as by social workers, many of whom were in dialogue with international birth control and eugenics movements. Reporters such as Webster and the Daily Gleaner newspaper itself also played an important role in both publicizing and sometimes explicitly promoting the birth control campaign. Yet it is Webster's reference to the rising expectations of the working classes that perhaps provides the biggest clue as to why the birth control debate erupted that particular summer and why it became so heated over the course of the next ten months, a period in which these "growing demands," the failure of the colonial government to address them, and the need for new answers were particularly visible and urgent. After all, the birth control debate came on the tail end of one of the largest labor rebellions in Jamaican history, a rebellion that not only demonstrated the potential of the working classes to disrupt order but also seriously challenged the legitimacy of British control over the colony and provided a substantial boost to the growing nationalist movement; in fact, many historians identify this moment as "the beginning of the end" of British rule in Jamaica. ${ }^{8}$

5. For the role of the Daily Gleaner as a medium for middle-class and elite views, see Moore and Johnson (2004:xix) and Carnegie (1973:162-76). Although it is difficult to determine the class of those who wrote under pen names, nearly all described themselves as "we" vs. a working class "them" (with some notable exceptions), suggesting they at least identified themselves with the middle and upper classes.

6. "Birth Control League Registered as Company," Daily Gleaner, June 30, 1939, p. 6.

7. "Birth Control Clinic," Daily Gleaner, August 28, 1939, p. 5.

8. The most detailed analysis of the rebellion and its aftermath is provided by Post (1978); see also Holt (1992) and Hart (1989, 1999). Bolland (2001) places the rebellion into the context of British Caribbean labor politics. 
This climate of disorder and frustration but also optimism for the future of a "new Jamaica" would open up the public arena to controversial issues such as birth control, lend the demands of birth controllers a particular sense of urgency, and shape the direction the birth control debate would take. The debate became a medium through which a number of islanders articulated their own understandings of what was behind the unrest, what the solutions were, what this "new Jamaica" should look like, and who would play what roles in its creation. Although for all sides of the debate these issues were linked to particular understandings of working-class Jamaican sexuality and family life that were envisioned in highly stereotyped forms, participants could not agree on how these issues were connected to poverty, what the "ideal" family would be, and who among them should be in charge of controlling the Jamaican family and nation. As a result, the birth control debate exposes some of the deep class, religious, political, and social divisions in Jamaican society during this particularly formative historical period, as well as unearthing some of the ambivalences between those who sought to lead the nationalist movement and the population they at once desired to help, mobilize, and control. If the labor rebellion signaled the beginning of the end of colonial rule in Jamaica, then the birth control debate highlights the tensions that would plague this transformation right from the beginning, as well as the ways these were intimately linked to reproduction and sexuality.

\section{“It WOULD BE DisASTROUS": FAMILY, ECONOMY, AND \\ ORGANIZATION, 1838-1938}

The concern over high rates of illegitimacy and "irregular" family structures in Jamaica voiced by both pro- and anti-birth controllers was not a new phenomenon in 1938. In fact, the perceived sexual looseness of slaves on Jamaican sugar plantations was a primary target of Christian clergy and missionaries arriving in the British colony from the sixteenth century on. This was sometimes a source of friction between church representatives and local planters (themselves producers of illegitimate children with slave mistresses) who had discouraged marriage among slaves until the abolition of the slave trade made increased reproduction (and thus, it was believed, more stable relationships) necessary (Austin-Broos 1997:31; Besson 2002:28). Attempts to instill Christian marriage and gender order into the population increased after slave emancipation in 1838 as the Church of England, Roman Catholic Church, Baptist Mission, and others expanded their network of churches, schools, and charitable organizations across the island. Illegitimacy also became a prominent issue among the local white population, British colonial authorities, and the emerging "respectable" black middle classes, who defined it as an exclusively lower-class (black) characteristic and a cause of 
societal disorder and criminality (Austin-Broos 1997:97; Moore \& Johnson 2004:96-136). In spite of efforts to control illegitimacy by reforming marriage, maintenance, and birth registration laws, however, many Jamaicans continued to lead their lives and have children in informal arrangements; indeed, illegitimacy rates hovered around 60 to 70 percent of all births in the period 1881-1950 (Roberts 1957:288). As such, it remained a source of consternation for those who saw the adoption of marriage as "an index of civilization, of movement from a state of slavery and from an African permissiveness" in the context of postemancipation Jamaican society (AustinBroos 1997:31).

The class and racial tensions underlying ideas about illegitimacy, and the birth control debate more generally, also had deep historical roots. Although emancipation brought formal freedom for hundreds of thousands of Africandescendent slaves, it left in place inequalities of access to wealth and land intimately linked to a color hierarchy in which those viewed as "darker" found fewer opportunities to climb the social, economic, and political ladder. While some former slaves did manage to obtain plots of land, rise to middle-class professional careers, and even enter politics, political power and control of the economy still remained largely in the hands of a small, unrepresentative white elite answering to the colonial office more than the local population. ${ }^{9}$ This racial inequality and the tension it threatened to ignite was, according to historian Patrick Bryan, largely dealt with "by declaring that Jamaica had no racial problem, and that, officially, no distinctions were to be made between Her Majesty's subjects on the grounds of color" (Bryan 1991:17). This denial did not, however, eliminate actual inequalities.

The dire situation of much of the population only increased when the economy in Jamaica began to shift towards the production of fruit (particularly bananas) for export in the late nineteenth century. Small-scale peasants found themselves forced off the land as multinational corporations such as the American United Fruit Company and Standard Fruit and Shipping developed a monopoly over fruit production and export on the island (Holt 1992:316-40). Joining these landless peasants in the wage labor pool and in growing Kingston in the 1920s and 1930s were thousands of West Indian migrants returning from Central America and other Caribbean islands, which had for decades willingly absorbed Jamaica's labor surplus but began to close their doors; from 1930-1934 some 30,000 emigrants were repatriated to Jamaica (Bolland 2001:301). According to demographer G.W. Roberts, this return migration coupled with declining mortality rates help explain popu-

9. The Legislative Council consisted of the governor (appointed by the British government) as president, the brigadier of the British regiment stationed in Jamaica, five officials, ten persons nominated by the governor (who were expected to support the governor or resign) and fourteen elected members (Hart 1999:3). 
lation growth on the island from 1921 to 1943 (a period in which average fertility rates were actually declining) particularly in the city of Kingston, which grew from a population of 63,700 in 1921 to 110,100 in 1943 (Roberts 1957:42-58). At the same time, the fruit industry was facing hardship due to crop destruction by hurricanes, banana disease in the 1930s, and the collapse of the American fruit market in 1935 (Holt 1992:358). Combined with the effects of the worldwide depression in Jamaica, these factors contributed to a massive unemployment problem and volatile economic situation, as work became difficult to find and laborers were forced to settle for "starvation wages" (Hart 1989:31).

This situation enhanced discontent and social tension, but also fed the growth of a series of organizations amongst all classes aimed at achieving political, economic, and social change, many of which would play prominent roles in the birth control debate. This included Citizens Associations formed across the island in the 1930s, the Jamaican Workers' and Tradesmen's Union (1936), and the short-lived Jamaica National League (1934-1936), which focused variously on monitoring the activities of local government branches and agitating for constitutional reform, land settlement, housing schemes, and worker's rights. Jamaica Welfare Limited (JWL), formed in 1937 with prominent barrister Norman Washington Manley at its head, also worked for "social, economic and cultural development of the peasants and small farmers of the island" (Bryan 1990:55) through cooperative agriculture and encouraging economic reform. Local branches of Marcus Garvey's workingclass-based Universal Negro Improvement Association (UNIA) addressed the reality of racial inequality, combining a black nationalist message with economic aid to increase black Jamaican self-sufficiency. Jamaicans also began to organize nationalist groups such as the Harlem-based Jamaica Progressive League (JPL), which brought its commitment to Jamaican self-government to the island in December 1937. That same year saw the beginning of publication of the progressive, nationalist newspaper Public Opinion, whose founders included members of a growing group of Jamaican Marxists (Bolland 2001:302-8).

Many nondenominational charitable organizations aimed at lessening the suffering of the working classes were also formed in the early twentieth century, often focusing specifically on issues of child welfare and the need for social and moral reform to accompany economic aid. Elite and middleclass women figured heavily in these types of institutions, which, as scholar Veronica Gregg (2005:48) has argued, provided a means for these women to work outside the home by "exploiting the patriarchal linkage of the so-called natural attributes of womanhood - virtue, patience, selflessness, nurturance to a predisposition for social work." This included the Child Saving League, the Women's League, and the Save the Children Fund, all created in the first three decades of the twentieth century and focused on providing meals and 
medical care for poor women and children, battling child prostitution, and providing employment for women in sewing, upholstery, and basket making (Bryan 1990:37-43). Although, as historian Rhoda Reddock (1994:181) has pointed out, most "tended more towards charity than solidarity" with working-class women, some of these organizations became increasingly activist, nationalist, and feminist in the 1930s. The Women's Liberal Club, for example, formed in 1936 by three black women social workers, outlined its mandate to

foster and develop a national spirit among the women of Jamaica; to encourage women to take an active and intelligent interest in local and world events ... to study politics, economics, government particularly, to study Negro History ... to study social and economic conditions, to advance the status of Jamaican women, socially and politically. (Bryan 1990:40-41)

The women of these organizations, particularly those in the Women's Liberal Club, would become some of the most outspoken advocates of birth control.

Even before the labor rebellion a handful of Jamaican social reformers showed interest in spreading birth control to the general population. Although there is no clear data on usage at the time, all who wrote in the Gleaner in the 1920s and 1930s accepted as fact that "artificial birth control" (most likely referring to the diaphragm and/or jellies, foaming tablets, condoms, and douching units) had been in use by middle- and upper-class Jamaicans for decades but was largely out of reach of the working classes. ${ }^{10}$ The idea that distributing artificial birth control more widely might help solve some of Jamaica's social and economic problems was discussed briefly by a union of teachers in Clarendon as early as $1925^{11}$ and by the Women's Liberal Club in 1937.12 J.L. Varma, the Indian doctor interviewed by Webster in July 1938, also held a talk on birth control and sex education in April 1938,13 after returning from a trip to England where he visited the International Birth Control Centre and the International Birth Control Association. ${ }^{14}$

10. Although in the 1938-39 debate artificial birth control was usually referred to vaguely as "mechanical apparatus," "appliances," and "chemicals," advertisements for diaphragms and jellies, available through mail-in orders or at local pharmacies, appeared sporadically in the Gleaner in the late 1930s. A reference to "rubber goods" also suggests the existence of condoms. A study by Judith Blake (1961) confirmed that in the 1950s, interviewees were aware of these as well as douching and foam tablets, although few working class/rural participants had access to them.

11. "Federation of Teachers in Clarendon," Daily Gleaner, December 1, 1925, p. 14.

12. "Woman's Club Au Revoir to Its President," Daily Gleaner, August 7, 1937, p. 11.

13. "Toc H Branch Hear Talk on Sex Education," Daily Gleaner, April 28, 1938, p. 10.

14. “Dr. J.L. Varma Back from the Motherland," Daily Gleaner, October 16, 1937, p. 15. 
Daily Gleaner editor, novelist, and social commentator Herbert George de Lisser had also begun to make birth control a topic of his popular editorial column, particularly after noticing some "alarming" trends in the 1921 island census:

\begin{abstract}
Those given as "white" were one thousand less than in the previous census; those given as "coloured" were fully ten thousand less. Those included in the category of "black" had gone forward; but amongst the black population of the islands there are many classes, and it is highly probable that the higher classes of the undiluted people of African descent control their birthrate to a certain extent. This too is in accordance with what has been observed in other countries. The lower classes hardly practice birth control, the higher classes do. Will this lead in Jamaica to the submerging of the latter? The higher classes do represent a superior intelligence as well as a better position: this is quite irrespective of any question of color. And it would be disastrous if the less intelligent, the less energetic, and the less progressive sections of the people were to swarm the limits of their ability, while the others steadily diminished. ${ }^{15}$
\end{abstract}

In other areas of the world, de Lisser noted, steps were being taken to deal with such "problems" through birth control and sterilization. He remained ambivalent about whether birth control was right for Jamaica or not, however, and seemed reluctant to open up his paper to the controversial topic; as he wrote on January 29, 1938: "woe unto the paper that advocated birth control. Its Catholic correspondents could not tolerate that; and many who are not Catholics would certainly object to it."16 Indeed fewer than two articles per month on the topic were featured in the paper before June 1938, few of which took a definite stance on the subject.

Only a few months later the Daily Gleaner would become an essential medium for the expression of both a fervent birth control campaign and its opposition, publishing on average 22 articles/letters per month on the topic from June 1938 to March 1939. But between January and June the political sit-

15. De Lisser, "Editorial," Daily Gleaner, November 4, 1929, p. 12. According to Roberts's data (1957:65), from the 1911 to 1921 censuses the black population had increased by around 30,000 from 77 to 78.1 percent of the population, while the colored population declined by around 10,000 from 19.6 percent to 18.3 percent of the population, and the white declined by 1000 from 1.9 percent to 1.7 percent of the population. However, as Roberts points out, these numbers are affected not only by fertility rates or who "practices birth control," but also by immigration, emigration, and mortality rates; in fact, average birth rates in Jamaica had been declining since the early 1900s.

16. De Lisser, "Random Jottings: As I See the World," Daily Gleaner, January 29, 1938, p. 12. 
uation had changed drastically in Jamaica, making certain types of arguments available and particularly appealing to an increasingly activist population.

\author{
"THE OBJECT OF CIVILIZATION": \\ THE 1938 LABOR REBELLION AND ITS AFTERMATH
}

On April 28, 1938, unrest broke out on the Frome estate in the parish of Westmoreland. Employees of the West Indies Sugar Company, frustrated with long waits at the pay office and the series of deductions taken from their checks, began throwing rocks at the pay clerk, who fired a shot into the air in response. Within a few days the laborers had called a strike, leading to a violent confrontation with police that left four dead and fourteen injured. On May 23, strikes and riots erupted in Kingston, which was brought "to a standstill as mobs surged through its streets halting streetcars, overturning cars and garbage cans, and firing shops" (Holt 1992:386). Main streets were blocked off by police barricades and cluttered with "debris of all sorts" and police, strikers, and bystanders met in violent clashes (Hart 1989:51). The unrest intensified with the imprisonment of labor activists Alexander Bustamante and St. William Grant in late May, and by June 1 it had spread to nearly every parish on the island. Labor mediation by Bustamante and his cousin Norman Manley, combined with the British government's commitment on June 5 to a "New Deal" policy of economic reform, helped bring the island under some semblance of control. Sporadic outbreaks, however, continued over the course of the next year.

Although labor unrest had been mounting across the British Caribbean, and within the island of Jamaica, the scale and violence of the summer of 1938 took most middle- and upper-class Jamaicans by surprise (Bolland 2001:311). "The main reaction," according to Ken Post (1978:308), "was to fall back upon the customary ideological position, and thus to emphasize repression and control." This reaction was dominated by fear of the black masses by those who saw their property destroyed and businesses threatened as employees went on strike. These middle- and upper-class Jamaicans rejected demands of the strikers, seeing the rebellion as an irrational upsurge by excitable "African savages" who had been misled by criminals or driven by greed, and thus should be answered by the imposition of police order and other methods of social control. However, Post (1978:316) also identifies "a minority voice [which] spoke out for amelioration as an alternative way of dealing with worker and peasant protest." This included not only labor leader Bustamante, who began organizing laborers into the new Bustamante Industrial Trade Union (BITU) before the rebellion sizzled out, but also the many middle- and upper-class lawyers, philanthropists, and social work- 
ers involved in the organizations discussed earlier. These men and women formed committees to investigate the rebellion and drew attention to the problems of the working classes in public hearings before the West Indies Royal Commission, sent from Great Britain to investigate the upsurge of rebellion across the British Caribbean. ${ }^{17}$

This sympathy for the poor was also emphasized by nationalist groups who saw the aftermath of the rebellion as an opportunity to challenge colonial rule and begin the reconstruction of a "new" Jamaica, a Jamaica in which, as envisioned by Public Opinion, workers and the middle classes allied together to develop "a truly national policy." 18 In advocating a cross-class alliance against the colonial government, these groups were careful to heed New York JPL member Jaime O'Meally's warning to "avoid race issues."19 This was taken up by Jamaica's first nationalist political party, the People's National Party (PNP), formed on September 18, 1938 with JWL founder Norman Manley at its head. At a speech before the Ward Theatre in Kingston that day, with labor leader Bustamante at his side, Manley announced the PNP's commitment to universal suffrage and stressed the importance of alliance between the middle classes and

[the] common mass in this country, whose interest must predominate above and beyond all other classes, because no man is democratic, no man is a sincere and honest democrat who does not accept the elementary principle that the object of civilization is to raise the standard of living and security of the masses of the people. (Post 1978:365-67)

Manley also called on Jamaicans to begin working towards eventual selfgovernment; within a few months sixteen branches of the PNP had been set up across the island (Post 1978:365-67).

All of this was encouraged by a general upsurge in activity and debate following the labor rebellion. As Gregg (2005:49) argues, across the British Caribbean

the aftermath of the 1935-38 uprisings, a period marked by social change, intense intellectual and political debate, and a sharpened focus, made available (temporarily) social and discursive spaces hitherto defined as unspeakable or nonexistent.

17. The Royal Commission was stationed in Jamaica from November to December 1938. For a discussion of the purpose and procedure of the commission, see Hart (1998:133-34) and Bolland (2001:383-84).

18. “Middle Class Prospects," Public Opinion, July 9, 1938, p. 1; quoted in Post (1978: 320-21).

19. O'Meally to Hart, “Letter," May 26, 1938, quoted in Post (1978:324). 
These spaces allowed not only for the rise of the organized labor movement and an open discussion of the problems of the masses, but also for articulations of other reform projects. This included a boost to the Jamaican feminist movement, as women organized to critique gender inequalities in judicial, educational, and political systems at the first-ever Women's Conference held on February 20-22, 1939, and it saw the election of the first female politician, Mrs. Mary Morris-Knibb, to the Kingston-St. Andrew Corporation Council in March 1939. 20

In this atmosphere mixed with fear of the lower classes and recognition of their real problems, frustration with colonial rule, and enthusiasm for the possibility of building a better Jamaica, the topic of birth control would be projected onto the public stage. The arguments debaters made would respond to and embody all of these tendencies, but the division between those who saw themselves as superior to and sought to control the lower classes and those who had sympathy for and sought to ally with them appears less clear in the context of the birth control debate. Here, dreams of social unity and progress sat alongside contempt for and fear of the dangerous potential of "the common mass," and the upper classes saw themselves divided by their understandings of what it meant to be a moral, responsible, and nationalist Jamaican.

\section{“THERE IS ONLY ONE ANSWER": BIRTH CONTROL, ECONOMY, AND SEXUALITY}

Those who publicized their support for birth control following the labor rebellion included a diverse group of black, "colored," and white, middleand upper-class, men and women occupying a variety of occupations and positions on the political spectrum. Most shared, however, a history of involvement with the various charitable and activist organizations that had made the fate of Jamaica their focus in the preceding decades and in particular after the labor rebellion. As well, they shared a passionate faith that spreading birth control to the working classes would help solve what they defined as Jamaica's most important problems, be it overpopulation, lack of land, the desperate situation of poor women, and, most often, the poverty and criminality they associated with high rates of illegitimacy on the island.

Prominent among these advocates were a number of physicians who were also active in one or more philanthropic and nationalist organizations. Dr. Varma, for example, was a member of JWL, represented the Jamaica Progressive League (JPL) before the Royal Commission, and was known as

20. Gleaner coverage of the conference included "Favour Sex Education in Schools," Daily Gleaner, February 24, 1939, p. 1 and "Women Deal with Big Problems," Daily Gleaner, February 28, 1939, p. 10. 
a "writer and lecturer on Social and Political matters" with "personal experience of India's fight for independence" (Thoywell-Henry 1940:185-86). ${ }^{21}$ Dr. McCulloch, who spent several years researching health and nutrition in Africa, was also a director of JWL and collaborated with Varma and others in developing a blueprint for rural reconstruction following the labor rebellion, a report that harshly criticized colonial policy and advocated cooperative landownership for Jamaican peasantry (Post 1978:368). Both doctors wrote a number of letters to the Gleaner advocating birth control; Varma also held several well-attended lectures on the topic, and McCulloch wrote a pamphlet entitled "Parenthood by Choice and Not by Chance," published by JWL in December 1938.22

Members of JWL also collaborated with Amy Beckford Bailey, a wellrespected teacher, secretary, and the cofounder of the Save the Children Fund, and vice-president of the Women's Liberal Club, in organizing a three-month islandwide lecture tour by British feminist and birth control advocate Edith How-Martyn from January until March 1939.23 Bailey, who wrote a number of articles for the nationalist Public Opinion as well, was a fervent critic of gender inequalities and also spoke out about the reality of racial inequality on the island. Judith DeCordova, a prominent white charity worker who had previously clashed with Bailey on the issue of racism on the island, was also an outspoken advocate of birth control. ${ }^{24}$ Joining these women was a large group of female social workers, nurses, and teachers who integrated calls for increased distribution of birth control into their program for social, political, and economic reform announced at the first Women's Conference in February 1939 after an impassioned speech by economist, social worker, and nurse May Farquharson on the topic of illegitimacy. These women also wrote letters to the Gleaner and spoke on the matter before the Royal Commission; as Veronica Gregg (2005:50) has pointed out, these activities were important

21. Varma, who regularly returned to India, also had contact with the birth control movement there, which was already in full swing by the 1930s (see Ahluwalia 2008 for the history of birth control in India).

22. "Parenthood by Choice and Not by Chance," Institute of Jamaica, West India Reference Library. Hereafter referred to as "Pamphlet 1938."

23. During the 1930s, How-Martyn had joined with other British and American birth control advocates (including Margaret Sanger) in promoting the cause of birth control abroad, particularly in India (see Ahluwalia 2008:26)

24. Judith de Cordova, in responding to accusations by politician Mary Morris Knibb that her Child Welfare Association did not allow black women to participate, claimed that Knibb was merely trying to create "what has never existed in the country - a Color Question," and argued that, with a few exceptions, she had experienced "nothing but indifference from the better offs among the black race, for their poorer brethren" (Gregg 2005:160). 
ways in which women of this generation carved out a space in the growing political movement.

The actions of birth controllers were also publicly encouraged by prominent Jamaicans including author and poet J.E. Clare McFarlane, planterpolitician G.R. Sharp, barrister E.E.A. Campbell, and former member of the Jamaica National League and "perennial Press contributor" (Carnegie 1973:107) Jas H. Blackwood, as well as a host of anonymous Daily Gleaner readers who wrote in support of the cause. They also had as an ally one of the rising stars of the island, barrister and politician Norman Manley who would go on to be recognized as one of Jamaica's five "national heroes" for his role in achieving independence for Jamaica in 1962; by 1938, he was already head of JWL and the leftist PNP. In the months after the rebellion, Manley utilized his public presence to promote the birth control cause, both through his work with JWL and in his widely attended and publicized testimony before the Royal Commission. ${ }^{25}$

Also crucial to the spread of the movement was the support and publicity the campaign gained through the Daily Gleaner under the editorship of Herbert George de Lisser. The Gleaner's long-standing reputation as a "respectable" paper ensured that it became a powerful political force, with the ability to fuel public debates, particularly under de Lisser's reign (Carnegie 1973:162). Described alternately as a deeply conservative racist who desired to contain women of all classes and as a truly avant-garde nationalist who championed lower-class Jamaican culture, de Lisser had a particular power to influence public opinion through his editorials and satirical "Random Jottings" column; as scholar James Carnegie (1973:172) has remarked: "It was [de Lisser's] words that educated Jamaicans drank in every morning."26 Although de Lisser provided plenty of space in the newspaper for opposition and encouraged everyone to write to the paper because "in a country like Jamaica ... we like to hear both sides of a question," 27 by August 1938 he had clearly stated that he had "no objection whatever to the people in general in the island being told or taught about birth control."28 The newspaper's journalists also propelled the birth control debate forward by interviewing advocates and the opposition, writing editorials, and making space on their

25. When asked by a commissioner whether or not he advocated birth control, Manley responded: "Definitely, yes, and I propose to take practical steps about it." "Mr. Manley on Degeneracy and Gross Corruption of Our Quasi-Democratic Institution," Daily Gleaner, November 15, 1938, pp. 16-17.

26. For the first opinion, see Gregg (2005:72); for a more positive assessment see Baxter (1970:82-83). For recognition of both sides of his personality, see Austin-Broos (1997:28) and Carnegie (1973:173-76).

27. De Lisser, "Editorial," Daily Gleaner, December 13, 1938, p. 12.

28. De Lisser, "Editorial," Daily Gleaner, August 19, 1938, p. 12. 
own pages for pro- and anti-birth control opinions. This included not only Aimee Webster, but also Daily Gleaner sports editor and political columnist Gordon St. Clair Scotter, "Men's World: A Weekly Page for Men” editor Ian Barry-Moore, and particularly Esther Chapman, a British permanent resident who edited the "Saturday Women's Page," where she published only probirth control articles and letters.

Yet birth control undoubtedly gained support and public attention during this period not only because of who the advocates were, but also because of the particular argument they made. In the context of a society struggling to deal with the unemployment, poverty, and unrest on the island brought to the forefront by the recent labor rebellion, birth controllers provided a very straightforward line of reasoning: overpopulation was Jamaica's biggest problem, and birth control was the solution. As Gordon Scotter wrote in July of 1938:

\begin{abstract}
Admirable as are the Land Settlement Scheme; proposals for developing minor industries here; large programmes of work by the P.W.D., to go on; these things can never be a complete solution of Jamaica's problems; they are indeed little more than patches on her weather worn economic garments, when what is needed is a whole new suit of clothes.

Like practically every other country in the world today Jamaica is suffering from an ever increasing population and a never increasing amount of land to put them on - the people of Jamaica grow, but the land itself doesn't ... there is only one answer as far as the future is concerned; population itself must be limited; and there is only one way of doing that, by Birth Control. ${ }^{29}$
\end{abstract}

Since birth control was something that the middle and upper classes apparently had well in hand and there was no shortage of organizations and social workers enthusiastic about taking on this task, this solution likely seemed manageable at the time; at least, more manageable than larger-scale economic and political reform. Although many birth control advocates also argued for structural changes before the Royal Commission or in committee reports, in the context of the birth control debate they consistently stressed that none of these changes could be successful if overpopulation was not tackled first. As McCulloch stated simply: if the population continued to grow, "instead of any improved standard of living for the people, in spite of the proposed new Land Settlement Scheme, standards will be lower than they are now."30

Although advocates usually claimed to have "discovered" this overpopulation problem during their travels through villages and Kingston streets

29. Gordon St. Clair Scotter, "Jamaica Needs Birth Control," Daily Gleaner, July 15, 1938, p. 9.

30. Pamphlet 1938. 
where they saw "so many children" 31 or because of the existence of high rates of unemployment, they were also influenced by worldwide concerns over population growth. This is unsurprising, as most of the advocates had been educated in Great Britain and, as mentioned earlier, the Gleaner had been publicizing such debates since the 1920s. As a result, birth controllers and their supporters consistently referred to overpopulation as a global phenomenon, as "the world's perpetual problem" 32 which was currently manifesting itself in Jamaica. Some advocates also utilized globally popular neo-Malthusian arguments that assumed a direct correlation between land, population, and economic prosperity. ${ }^{33}$ In his introduction to Edith HowMartyn's lecture at the Ward Theatre, for example, Norman Manley stressed the "fact" that Jamaica was a country with 1.25 million people (an estimate at best, considering there had not been a census since 1921) on only 2 million acres of cultivable lands, of which "at least 75 percent" was not really worth cultivating; this worked out to little more than one acre per man, which clearly did not fit with the estimates of American economists that each person needed two and a half acres of land to lead a comfortable life. ${ }^{34}$

The arguments of birth controllers in Jamaica also took on features of the various "eugenics" movements that spread across Europe and the Americas during the 1920s and 1930s. These movements advocated policies of "better breeding," in which those deemed "eugenic" (usually white, upper-class citizens of European and North American countries) were encouraged to propagate while the "dysgenic" (lower class, mentally ill, and/or members of "inferior" races) were discouraged, either through distribution of birth control or direct sterilization. ${ }^{35}$ Some birth control advocates such as Varma had actually attended eugenics conferences in Great Britain and elsewhere, ${ }^{36}$ and these movements were also covered by the Gleaner. Although most advocates, in keeping with official policy, avoided explicit arguments about racial

31. Hard Facts, "Letter," Daily Gleaner, August 11, 1938, p. 12.

32. Peter Marteen, "Letter," Daily Gleaner, November 11, 1930, p. 12.

33. According to Malthus's 1789 Essay on Population, because population grows at an exponential rate while agricultural resources increase at a linear rate, if it is not restrained this will lead to wide-scale poverty, starvation, and unemployment (though he advocated moral restraint, rather than birth control). For the revival of Malthusian logic and its use as a justification for birth control in England in the late nineteenth and early twentieth centuries, see Soloway (1982:48-69); in India, see Ahluwalia (2008:23-53); in Puerto Rico, see Briggs (2002:81-108).

34. “Mrs. How-Martyn's Lecture on Birth Control at Ward Theatre," Daily Gleaner, February 2, 1939, p. 21.

35. For descriptions of eugenics movements in Latin America, see Stepan (1991); for the United States, see Stern (2005); for England, see Soloway (1982).

36. "Dr. J.L. Varma Back from the Motherland," Daily Gleaner, October 16, 1937, p. 15. 
degeneration when arguing for birth control in public arenas and denied any plans for forced sterilization (which, according to one Gleaner reader would be "too much like Germany" and thus "would never be tolerated under British Rule"), ${ }^{37}$ they frequently utilized the language of "better breeding." Advocates reiterated the danger created by the overbreeding of "the wrong class" 38 of "the ignorant, the immature, the under-nourished, the criminal, the diseased and the feeble-minded" rather than "the educated, cultured and well-nourished classes." ${ }^{39}$ As May Farquharson warned those in attendance at the Women's Conference, excessive breeding by those who were not "fit" could only lead to "depreciation in the condition of their people." 40

But if concerns about overpopulation and overbreeding of the lower classes were recognized as worldwide problems, advocates also claimed that these issues took on a particular urgency in Jamaica because of the high rates of illegitimacy on the island. For birth controllers, the production of children outside of legal marriage was especially dangerous, for, as de Lisser argued, these children "are apt in time of trouble to behave with the same irresponsibility as brought them into being." 41 Varma told Webster that the illegitimate female child was "more liable to turn a prostitute than her sister who has been born in wedlock," 42 and others agreed that the illegitimate male child usually ended up swelling the ranks of the unemployed and riotous. ${ }^{43}$ When Esther Chapman held a competition for letters addressing "Birth Control and Illegitimacy" on her "Saturday Woman's Page" in July 1938, for example, one of the winning submissions pointed out that most birth control advocates seemed to believe that "there would not have been any rioters or strikers, if Jamaica had not produced so many illegitimate children, in order to form that vast throng that caused so much trouble here about a month ago." 44 Indeed, this connection was implicitly or explicitly made by many writing to the Gleaner in support of birth control.

By pointing to high rates of illegitimate reproduction, middle-class and elite Jamaicans provided a simple and solvable explanation for the labor

37. G.T.L., "Letter," Daily Gleaner, July 9, 1938, p. 36.

38. Gordon St. Clair Scotter, "Jamaica Needs Birth Control," Daily Gleaner, July 15, 1938, p. 9.

39. Mountain Man, “Letter," Daily Gleaner, January 13, 1939, p. 12. See also note 38.

40. "Women Deal with Big Problems," Daily Gleaner, February 28, 1939, p. 10.

41. De Lisser, "Editorial," Daily Gleaner, June 22, 1938, p. 12.

42. J.L. Varma, quoted in "Toc H Branch Hears Talk on Sex Education," Daily Gleaner, April 28, 1938, p. 10.

43. See S.M., "Letter," Daily Gleaner, June 25, 1938, p. 36; also J.L. Varma, interview with Aimee Webster, "It Does Interest You - Birth Control," Daily Gleaner, July 14, 1938, p. 16.

44. Thinker, "Letter," Daily Gleaner, July 16, 1938, p. 36. 
rebellion; it was also an explanation which placed the blame for the unemployment and poverty of the working classes primarily in their own sexual and familial practices. In making these claims, middle- and upper-class birth control advocates exposed some of the deep reservations and stereotypes they held regarding the "common mass" of people they sought to ally with in building Jamaica's future. For birth controllers, the high levels of illegitimacy symbolized "rampant" sexual promiscuity among these classes, which was explained as being a "hang-over of slavery," 45 a response to not having "the means of recreation," 46 a result of limited contact with the "enlightened" classes, ${ }^{47}$ or even, in a rare moment of explicit reference to color, as a racial trait: according to Dr. Varma, it was "a psychological fact that a negro is a more highly sexed individual than his Caucasian brother." 48 The children of such immoral and irresponsible parents were destined to become prostitutes, criminals, and rioters because "the lower classes of Jamaica just cannot realise the responsibilities and obligations of parenthood: they will not reach that stage of mental evolution for decades to come." 49 These arguments relied on a highly stereotyped image of the "irresponsible Jamaican father" who "is a most unreliable person where his offspring is concerned," 50 and the "ignorant Jamaican mother" who was like the old woman "who lived in a shoe who had so many children because she didn't know what to do." 51 As the opening of McCulloch's pamphlet read:

Jamaica is crowded today with sickly children many of whom have no support from their fathers; their mothers have to deny themselves the poorest quality of food, of clothes and of house so as to feed and clothe these little ones. ${ }^{52}$

As advocates doubted the potential of the Jamaican father to reform his ways, birth control could at least reduce the number of children produced and the suffering on the side of the woman.

45. "An Economic Idiot," in a letter to the editor, argued that slave women would breed indiscriminately in order to gain the favor of the master, Daily Gleaner, July 22,1937 , p. 10. Lotha Kentish, in another letter to the editor, claimed illegitimacy was a result of the lower classes' inability to "govern and control their passions," being only one generation removed from "semi-barbarity ... and slavery," Daily Gleaner, July 16, 1938, p. 36.

46. See Beatrice Thompson, "Letter," Daily Gleaner, July 16, 1938, p. 36.

47. Violet Allwood, in an interview with Webster, "What's Wrong with Village Life?," Daily Gleaner, July 5, 1938, p. 16.

48. “Dr. J.L. Varma Back from the Motherland," Daily Gleaner, October 16, 1937, p. 15.

49. G.T.L., "Letter," Daily Gleaner, July 9, 1938, p. 36.

50. V.S., "Letter," Daily Gleaner, July 9, 1938, p. 36.

51. An Economic Idiot, "Letter," Daily Gleaner, July 19, 1938, p. 12.

52. Pamphlet 1938. 
But if they displayed sympathy toward the troubles of Jamaican lowerclass women, birth control advocates (including those who would be considered among the growing group of "feminist" women on the island) stressed more often the threat these women's uncontrolled reproduction held to the new nation they were planning to build in the aftermath of the rebellion. More than just the cause of the labor rebellion, "improper" Jamaican families became, in the eyes of advocates, the key problem holding Jamaica back from ever truly progressing. Working-class promiscuity was, according to de Lisser, "seriously undermining our social fabric," 53 while others described illegitimacy as one of the "twin scourges of this island" (along with venereal disease) $)^{54}$ and as "Jamaica's most vital problem"55 which could fuel "discontents leading to bloody wars, or to what is known in these days as communism." 56 For those interested in working towards social reform, raising the standard of living and achieving self-government after the labor rebellion, this spelled disaster as the family was the "basis of social organisation" of the nation. ${ }^{57}$ As May Farquharson proclaimed, speaking on the topic of illegitimacy at the Women's Conference: "If the babies keep on coming at the rate they are coming at this very moment, we will have to give up all idea of these things that we want to see in Jamaica." 58 Indeed, without birth control, argued Judith de Cordova, Jamaica was "doomed." 59

If the working classes' sexuality and reproduction was holding the island back, middle-class and elite doctors and social workers were more than willing to assume responsibility for setting Jamaica on the right path, and they were profoundly enthusiastic about their ability to do so. Based on the assumption that working-class parents had children solely because they were "ignorant" of birth control methods, most advocates believed that providing wider access to birth control would be enough to entice them to reduce their birth rates, and thus, the reproduction of illegitimate children. To that effect, Dr. Varma claimed to have access to a method (likely a diaphragm) which was successful "99 percent of the time," cost less than eight shillings per annum, and could be easily distributed at birth control clinics, which could also offer biannual examinations of the "apparatus." $60 \mathrm{McCulloch}$ 's earlier mentioned pamphlet similarly stressed the authority of doctors to deal

53. De Lisser, "Editorial," Daily Gleaner, June 22, 1938, p. 12.

54. L.M. de Carteret, "Letter," Daily Gleaner, July 9, 1938, p. 36.

55. S.M., "Letter," Daily Gleaner, June 25, 1938, p. 36.

56. De Lisser, "Editorial," Daily Gleaner, September 8, 1938, p. 12.

57. "Women Deal with Big Problems," Daily Gleaner, February 28, 1939, p. 10.

58. "Women Deal with Big Problems," Daily Gleaner, February 28, 1939, p. 10.

59. "Prominent Citizens Give Their Views on Emancipation," July 30, 1938, p. 27.

60. Interview with Webster, "It Does Interest You - Birth Control," Daily Gleaner, July 14, 1938, p. 16. 
with issues of reproduction. Female social workers and teachers also spoke before the Women's Conference and on the pages of the Gleaner, touting their particular awareness of the needs of poor families and stressing the important role social workers could play in the campaign. ${ }^{61}$ In response, a number of Gleaner readers suggested these women should set up a local "Mother's Bureau" to teach the responsibilities of motherhood and distribute birth control ${ }^{62}$ and argued that all clinics should operate under close supervision by doctors to ensure birth control methods were used properly. ${ }^{63}$

Advocates also appeared particularly confident that they could implement this program without the support of a British colonial government increasingly criticized as insufficient in the aftermath of the rebellion. Varma assured his supporters that the program, at least at first, would have to be enacted primarily by wealthy and willing Jamaicans, ${ }^{64}$ and the delegation from the Women's Conference likewise stressed that the imposition of proper "family life" would rest largely on the activity of social workers, asking only that the government encourage the medical officers of the government and parochial boards to "include Birth Control advice in their Services for mothers." 65 As Gleaner editor de Lisser insisted, if birth control would be widely advocated in Jamaica, it would not be because of any recommendation by the Royal Commission, but
because of our own appreciation of our circumstances; and the necessary advice will be given, if not by our Government, at any rate by private individuals which is indeed already, to a certain extent, being done ... we ourselves will have to attend to our population problem and to our wages question; these are matters, we repeat, with which only Jamaica herself can deal. 66

As McCulloch insisted, those targeted by birth control propaganda were "our people," who would be best attended to by JWL, an organization no one

61. See "Women Deal with Big Problems," Daily Gleaner, February 28, 1939, p. 10.

62. Justice for Women, "Letter," Daily Gleaner, July 6, 1937, p. 10; also An Economic Idiot, “Letter," Daily Gleaner, July 19, 1938, p. 12.

63. For different opinions on the nature of the clinics, see Ian Barry Moore, "Of Many Things," Daily Gleaner, July 23, 1938, p. 32; Agenesis, "Letter," Daily Gleaner, August 29, 1938, p. 12; Justice for Women, "Letter," Daily Gleaner, July 6, 1938, p. 10; "How Large Is Your Family?," interview with How-Martyn, Daily Gleaner, January 12, 1939, p. 16; de Lisser, "Editorial," Daily Gleaner, January 12, 1939, p. 12.

64. Interview with Webster, "It Does Interest You - Birth Control," Daily Gleaner, July 14, 1938, p. 16.

65. "Women Deal with Big Problems," Daily Gleaner, February 28, 1939, p. 10.

66. De Lisser, "Editorial," Daily Gleaner, December 6, 1938, p. 12. 
could deny was "a friend of the people." 67 By linking reproduction to the fate of the island and proposing birth control as the only truly adequate response, birth controllers thus managed to place themselves at the core of a Jamaican future based on the reform of working-class sexual and family practices by morally and technologically enlightened doctors and social workers.

\section{"The Word Jamaican DiE With ThEM": OPPOSITION TO BIRTH CONTROL}

This vision of what Jamaica should look like after the rebellion, who would build it, and how, however, was not shared by all of those who read and contributed to the Daily Gleaner. By invoking the issue of illegitimacy and placing themselves as the authorities on the issue, in particular, birth controllers had stumbled into a moral arena that had largely been the domain of the Christian churches and missionary groups. Although these groups had seen some of their official influence over Jamaican politics decline over the past decades, they proved unprepared to relinquish their authority over morality on the island and quickly became the loudest critics of the birth control movement. ${ }^{68}$ Respected Roman Catholic clergyman Father Joseph Krim came out strongly against the birth controllers in highly publicized sermons as well as in a four-part, full-page series of articles written for the Daily Gleaner, and the leaders of the nine major Christian denominations announced their "almost universal" opposition to birth control before the Royal Commission in November 1938.69

Church and religious leaders rooted their criticism of birth control and its advocates biblically, claiming it went directly against God's Genesis 1:28 command to "go forth and multiply and replenish the Earth." But birth control advocates also likely enhanced Christianity's reaction by suggesting, for example, that "religion has failed to find a solution to the lure of sex among

67. W.E. McCulloch, "Letter," Daily Gleaner, January 23, 1939, p. 12.

68. This included the disestablishment of the official Church of England in 1870; churches also lost their traditional monopoly over school administration at the turn of the century, and they faced declining funds as they lost links with international chapters (Moore \& Johnson 2004).

69. "Heads of 9 Denominations Tell Commissioners about Conditions in Island," Daily Gleaner, November 11, 1938, p. 16. Even representatives of the Church of England in Jamaica remained steadfastly opposed until as late as February 1939, despite the tacit approval of birth control given by the Church of England in Great Britain at the Lambeth Conference in 1930 (see Soloway 1982:251-55), which was covered by the Daily Gleaner ("Decisions Reached at Recent Lambeth Conference," Daily Gleaner, August 23, 1930, p. 1). 
unmarried people." 70 These accusations tapped into the insecurities of many religious leaders, who were unable to deny that their Christianizing mission thus far had largely failed to control Jamaican working-class sexuality. Rev. Walter Brown of the Church of England admitted to the Royal Commission that Jamaica had "definitely" been "going backwards" in terms of increased promiscuity, despite the advent of "civilization."71 Bishop Hardie, the head of the Church of England in 1939, also relented that they had "no right to speak except in shame, for in spite of the work of the Churches of Jamaica, the percentage of illegitimate births has hardly fallen at all." 72 Unlike the birth controllers, however, few saw this as proof that religious leaders were no longer a relevant source of moral authority on the island or that Christian doctrine had expired as a possible guide for people's lives. Krim criticized those who "declared self-control and chastity impossible," accusing them of promoting a sort of "MORAL DEFEATISM" that would lead to "mortal anarchy."73 A. Wesley Knott of the Baptist Union wrote:

That our people cannot be called "nice" is a bitter pill to swallow, but I am convinced that they are not beyond the point of redemption, provided a real helping hand is given them - larger opportunity, backed up by honest and fair means of attaining a higher ideal. ${ }^{74}$

Or, as the anonymous "Catholic Layman" put it: "The Church has not failed. Her ideas have not been tried and found wanting. They have been found difficult." 75

This clerical response to the birth control campaign also included a larger attack on the "New Morality" being promoted by upper- and middle-class Jamaicans which, according to Rev. E.L. Maxwell of the Church of England, had been gradually replacing Christianity since the Great War. ${ }^{76}$ Krim suggested that the single purpose of his Gleaner series was to "pass judgment on the newer morality before the system is foisted on a heedless people," and he described as "pseudo-morality" any notion that the material benefits of birth

70. G.G.M., "Letter," Daily Gleaner, July 23, 1938, p. 36.

71. "Heads of 9 Denominations Tell Commissioners about Conditions in Island," Daily Gleaner, November 11, 1938, p. 16.

72. "Church of England's Stand on Birth Control," Daily Gleaner, February 18, 1939, p. 6.

73. Krim, "Marriage as a Sacred Contract," Daily Gleaner, October 5, 1938, p. 9.

74. A. Wesley Knott, "Letter," Daily Gleaner, February 3, 1939, p. 12.

75. Catholic Layman, "Letter," Daily Gleaner, February 12, 1932, p. 6.

76. "Rector Condemns Practice of Illicit Birth Control," Daily Gleaner, February 9, 1939, p. 24. 
control made it morally acceptable. ${ }^{77}$ Although this challenge included a critique of doctors who were seen as promoting birth control in order to acquire more money from patients, ${ }^{78}$ middle-class and elite women took most of the heat for promoting and practicing this dangerous "New Morality." Even though female birth controllers were usually more concerned with protecting the nation from illegitimate children than "liberating" working-class women, religious leaders used the opportunity to critique middle-class women's own use of birth control and the women's movement in general. As Krim pronounced in the Gleaner:

The entire Birth Prevention movement is part of the scheme for emancipating womanhood - from what? First from a husband, now from children. No wonder the movement, originating in minds that had lost hold of Christianity, ends in broken homes, and the loss of God himself! ${ }^{79}$

Father Walter J. Ballou likewise painted a grim picture of "the willfully barren wife" who was a "social failure, a shirker, a slacker, a betrayer of home and of country." 80 The sexual and family practices of middle- and upper-class Jamaicans were thus portrayed as being as threatening to the future of a "new Jamaica" as those of the working classes; in this context, only the truly morally advanced religious leaders could direct Jamaica towards its proper path.

If much of the religious-based opposition was focused on the issue of morality, however, religious leaders were also among Jamaicans who used the birth control debate as an opportunity to critique the unequal economic system on the island and the collaboration of middle- and upper-class Jamaicans in colonial economic and political repression. They challenged the legitimacy of claims that the island was "overpopulated" 81 arguing instead that the root of Jamaica's poverty problem was not too many children, but poor housing, low wages, lack of native industries, and the unequal distribution of land. Addressing these problems through economic reform rather

77. Krim, “The Pseudo-Morality Neo-Paganism Rampant Here," Daily Gleaner, August 9, 1938, p. 13.

78. Carl Preston, “Letter," Daily Gleaner, February 7, 1939, p. 18.

79. "Priest Scores Birth Control Propaganda," Daily Gleaner, January 19, 1939, p. 10.

80. From Catholic Opinion magazine, "So-Called Birth Control - A Social Menace," reprinted in Daily Gleaner, January 24, 1939, p. 24.

81. Walter J. Ballou referred to overpopulation as "a hobgoblin without foundation in fact: it is unreasonable and unscientific" and claimed Jamaica could support three times its current population, "So-Called Birth Control - A Social Menace," Daily Gleaner, January 24, 1939, p. 24. Rev. J.J. Dillon pointed out that there were still 2,848,160 acres of mostly undeveloped land with a population of only 1,250,000, thus fears of overpopulation were essentially groundless, "Letter," Daily Gleaner, February 11, 1939, p. 12. 
than through birth control propaganda would either relieve the problem of illegitimacy, ${ }^{82}$ or at the very least prevent the poor from becoming morally corrupt as well. As Rev. Walter J. Ballou, SJ, wrote in an article for the journal Catholic Opinion (reprinted in the Gleaner):

Poverty is an economic difficulty and must be met by an economic remedy, not by moral perversion. The place to remedy poverty is in the factory, not in the home, and the poor, God bless them, would be the first to say so. ${ }^{83}$

At times, this criticism of the unequal economic system and those who benefited from it went so far that men such as Father Krim were accused of preaching "a virulent form of class war." 84

Echoing these arguments were men such as J.A.G. Edwards, a prominent member of the Bustamante Industrial Trade Union, who also wrote a number of letters to the Gleaner criticizing middle-class birth control advocates. Edwards, whose organizational roots began with Garveyite organizations and the Citizens Associations, argued that birth control advocates blamed poverty and unemployment on overpopulation in order to "keep the bulk of the people in ignorance of the true cause of the conditions affecting them, with the hope of further achieving their selfish ends." It was ironic, he thought, that it was the very descendents of slave owners, whose own immorality had encouraged the illegitimacy problem, who were now advocating birth control. Edwards argued that birth control was "against spiritual laws" as well as

against the true principles of a strong and firm Government. Don't forget that the strength of a nation lies firstly in its moral and spiritual relationship with the cause of its existence (Bible history supports this); secondly, in its manpower, as the practice of war reveals. ${ }^{85}$

St. William Grant, a member of the UNIA and labor leader Bustamante's right-hand man for a number of years, also held a meeting at Market Square where he denounced birth control, claiming it would decrease the manpower of laborers and was little more than a false cure-all used to deflect from the real problems at hand. 86

82. One reader suggested that better wages would decrease illegitimacy by 90 percent. Stanley Vernon, "Letter," Daily Gleaner, October 20, 1938, p. 23.

83. Rev. Walter J. Ballou, "So-Called Birth Control - A Social Menace," Catholic Opinion, reprinted in Daily Gleaner, January 24, 1939, p. 24.

84. W.E. McCulloch, "Letter," Daily Gleaner, January 23, 1939, p. 12.

85. Edwards, "Letter," Daily Gleaner, April 11, 1938, p. 25.

86. “Unionist against Birth Control Move," Daily Gleaner, January 28, 1939, p. 18. 
Jamaicans writing to the Daily Gleaner also used the topic of birth control to question the project and authority of the middle/upper-class nationalist movement represented by Manley, JWL, and the PNP. Sydney S. Foulkes of Black River announced his surprise to see "a man of his [Manley's] calibre" promoting birth control when it was so obviously against Christian principles, ${ }^{87}$ and engineer Braham T. Judah, after Manley condemned those who went out and "spawn[ed] over all the street" in a lecture, exclaimed: "What language! And this man is attempting to create a National Spirit in Jamaica!!!"88 Judah thought it was a pity that the PNP had "dragged into their politics a matter of faith and morals." 89 JWL was also accused of catering to "the modern whims of an esoteric few" through its promotion of birth control, when it was supposed to be "a Body which should act for the Welfare of the entire country." 90 Carl Preston, one of the few Gleaner readers to identify himself as a "poorer" Jamaican, criticized "those wealthy ones who are now favouring Birth Control," and accused them of trying to destroy "the Jamaican nationality" rather than lead it toward independence; did birth controllers, he asked, want a situation in which, when the people die, "the word 'Jamaican' die[s] with them, thus leaving our dear little Island to the benefit of foreigners?"91

Indeed, JWL's foreign backing provoked particular criticism from many of those opposed to their involvement in the birth control movement.92 According to the anonymous "Genesis," JWL "may as well be called Foreign Fruit Corporation's Welfare Unlimited," because its American funding source created a situation where "we have the anomaly of financially powerful outsiders dictating a social policy which large social groups, headed by experienced and patriotic Jamaicans, have unequivocally condemned."93

"Examiner" likewise stressed that the involvement of "soulless ... blind ... large alien corporations" seriously damaged the credibility of JWL to claim it was working for Jamaicans. ${ }^{94}$ For his part, Manley attempted to de-link JWL from these American backers by asserting before the Ward Theatre in January 1939 that "the fruit companies have not initiated this programme ...

87. Sydney S. Foulkes, "Letter," Daily Gleaner, February 7, 1939, p. 18.

88. Braham T. Judah, "Letter," Daily Gleaner, January 28, 1939, p. 12.

89. Braham T. Judah, "Letter," Daily Gleaner, January 27, 1939, p. 12.

90. Herbert N. Bell, "Letter," Daily Gleaner, January 27, 1939, p. 12.

91. Carl Preston, "Letter," Daily Gleaner, February 7, 1939, p. 18.

92. JWL was funded by the UFC and Standard Fruit, who agreed to donate one cent to a local development organization for every nine bunches of Jamaican bananas exported from the island (Post 1978:89).

93. Genesis, "Letter," Daily Gleaner, January 23, 1939, p. 12.

94. Examiner, "Letter," Daily Gleaner, February 27, 1939, p. 12. 
they have not got any control whatever over our activities,"95 and the PNP also printed an announcement in the Gleaner in late January asserting that "Birth Control Forms No Plank of [the] Party," despite Manley's involvement in the campaign. ${ }^{96}$

This did not, however, prevent the opposition from challenging the allegiances of birth controllers; rather, these only intensified with JWL's support of British feminist Edith How-Martyn's islandwide lecture tour. Numerous letters to the Gleaner questioned her role in the spread of birth control in Jamaica, asking whether hers was really the "kind of mentality that ought to have been imported to 'enlighten' (?) the people of this island." 97 Many responded in particular to a letter How-Martyn wrote to the Gleaner in which she argued that those insulting birth controllers were also insulting the British government (which she claimed supported birth control in England) and "as loyal subjects if for no other reason we should resent such imputations being cast on His Majesty's Government." 98 As the anonymous "Old Timer" replied: "This English lecturer will not succeed in making a fetish of a British Government sanction to those of us who know the history of British Governments." 99 Others were offended by anti-Roman Catholic comments How-Martyn made at a lecture at the Ward Theatre in Kingston; Major J.J. Hallinan, Director of Medical Services in Jamaica, for example, explained his departure from the lecture by pointing out that, unlike in Mrs. How-Martyn's Britain, "Jamaica prides itself upon the happy tolerance and cooperation that exists between all of its churches and creeds."100 Perhaps, as one Josh B. Phillips wrote, How-Martyn should "leave the tropics to tropical people and the temperate zone to temperate people."101

For their part, birth control advocates attempted to justify their support for Edith How-Martyn's tour and reassert their own nationalism by stressing that she was a privately interested British citizen, rather than a member of the colonial bureaucracy, who had herself been imprisoned by that government during the suffrage movement in Britain. Described as an exceptional "tribute to white people," she was praised at a dinner at the Esquire Restaurant on March 18, 1939, days before her departure, for being

95. "Mrs. How-Martyn's Lecture on Birth Control at Ward Theatre," Daily Gleaner, February 2, 1939, p. 21.

96. "Birth Control Forms No Plank of [the] Party," Daily Gleaner, January 31, 1939, p. 13.

97. H.M. Watson, "Letter," Daily Gleaner, February 2, 1939, p. 12.

98. Edith How-Martyn, "Letter," Daily Gleaner, February 4, 1939, p. 12.

99. Old Timer, "Lecture," Daily Gleaner, February 10, 1939, p. 12.

100. J.J. Hallinan, "Lecture," Daily Gleaner, January 26, 1939, p. 12.

101. Josh B. Phillips, “Letter," Daily Gleaner February 2, 1939, p. 12. 
the type of link they wanted with England and Jamaica. It was a link not so much connected with monthly pay cheques or the Colonial Office, but it was one of culture and Jamaica would always welcome her again (hear, hear). ${ }^{102}$

At the end of that same dinner, held both to bid How-Martyn farewell and to honor Councilor Mary Morris-Knibb for "her brilliant achievement in making history being the first woman to enter the political life of the island," the birth controllers also demonstrated that they were prepared to move ahead with their vision regardless of the opposition. Edith How-Martyn closed her farewell speech by expressing her thanks to her supporters, dismissing those who opposed her, and also announcing the formation of the first-ever Jamaica Birth Control League. ${ }^{103}$ Anyone seeking information was told to direct their enquiries to social worker Miss May Farquharson, who would go on to become the League's Honorary Secretary and Treasurer. Joining her on the Board of Directors were prominent doctors McCulloch, Varma, Charles Levy, H. Robertson, and George P. Allen, as well as planter, politician, and JWL member Rudolph Burke, wealthy merchant, industrialist, and drug manufacturer Cecil B. Facey, and Aubrey Allwood. ${ }^{104}$ Although Edwards and others would continue to write letters to the Gleaner opposing birth control following this announcement, in general the birth control debate, at least through the medium of the Gleaner, died out temporarily; compared to the thirty-five articles published on the topic of birth control in March of 1939, none were published in April and only two in May.

\section{CONCLUSION}

Those in attendance at the Esquire Restaurant that day heard a number of enthusiastic speeches regarding the rapid advances Jamaicans had made towards building a new Jamaica in the aftermath of the labor rebellion. Councilor Mary Morris-Knibb gave an inspiring speech about Jamaicans taking steps to remedy their own situation and "save Jamaica" by "taking care of the children." Wishing How-Martyn farewell, Amy Bailey remarked:

102. "Mrs. Morris-Knibb Honoured for Blazing Trail for Women in Political Life of Island," Daily Gleaner, March 20, 1939, p. 16.

103. "Mrs. Morris-Knibb Honoured for Blazing Trail for Women in Political Life of Island," Daily Gleaner, March 20, 1939, p. 16.

104. "Birth Control League Registered as Company," Daily Gleaner, June 30, 1939, p. 6. 


\begin{abstract}
I want you to take away with you the picture of the representative body of middle class Jamaicans, who are proud of the fact that they are Jamaicans, who are all serving in one way or the other for the benefit of Jamaica. ${ }^{105}$
\end{abstract}

Honorable E.E.A. Campbell similarly remarked that it was "amazing how so many great things had happened in Jamaica during the last ten months" and declared that Jamaica "had made more progress in ten months than she had during the first century of emancipation.”106

It is no coincidence that the announcement of the formation of the Birth Control League concluded such an event; after all, birth control had become an integral part of the program middle- and upper-class Jamaicans had launched following the labor rebellion. The many doctors, social workers, and other professionals had found in overpopulation a problem that they believed themselves more than equipped to deal with, even without the support of a government that was increasingly falling into disfavor. By stressing the importance of family and linking the need to control illegitimacy and working-class reproduction to the fate of the nation, these actors thus carved out an important role for themselves in the march towards independence.

The enthusiasm and ideals shared by this group of men and women would indeed be integral in guiding the island towards independence in 1962. But the birth control debate also reveals the lack of consensus surrounding this particular trajectory from its inception. Jamaicans from a variety of backgrounds, though less unified than the birth control advocates, had their own understandings of Jamaica's problems and solutions that led them to question the authority and integrity of those taking command after the rebellion. Like the advocates, they recognized the importance of morality in the creation of Jamaica's future, but defined that morality based on religion or a sense of social justice rather than "responsible" reproduction. If some advocated limiting families through self-control while others suggested large families might provide the manpower and nationalist base valuable to the island's future, all agreed that the vision of birth control advocates and the organizations they were involved with was seriously flawed.

These conflicting views were perhaps less visible in the months after the rebellion if one looks only at the political sphere during this period, where nationalist Manley and labor leader Bustamante were working together to settle the labor rebellion and standing side by side at the opening session of the PNP. However, as labor historian Bolland (2001:324) points out, "their temporary coalition barely hid deeper divisions that were to emerge in the

105. "Mrs. Morris-Knibb Honoured for Blazing Trail for Women in Political Life of Island," Daily Gleaner, March 20, 1939, p. 16.

106. "Mrs. Morris-Knibb Honoured for Blazing Trail for Women in Political Life of Island," Daily Gleaner, March 20, 1939, p. 16. 
following year and that subsequently split the labor and nationalist movement in Jamaica." According to Bolland (2001:333), by mid-1939 the link between these two movements had begun to disintegrate, and the nationalist movement led by Manley and the PNP lost its root in labor, a situation which "remained a serious and persistent problem in Jamaica." While disagreements over the desirability of birth control in 1938 were not likely the main cause of this split, they do reveal early challenges by religious and labor leaders to the ideological and strategic plans of middle- and upper-class professionals and nationalists.

The birth control debate also exposes the social and cultural distance between these middle- and upper-class nationalists and the "common mass" of the island, precisely at the moment when they were supposed to be uniting as Jamaicans to develop a "truly national policy." If nationalists believed that the interests of the masses "must predominate over all others" (as Manley claimed before the PNP), they also seemed deeply skeptical about the ability of the working classes (stereotyped as ignorant and sexually/socially immoral) to define interests and act in ways fit for the construction of a stable independent nation. This nationalist agenda thus seemed to rely not only on support for, but also control of, working-class needs and desires. Although birth control itself as an issue would fade out of the public eye temporarily, this perceived need to reform working-class sexual behavior remained integral to the middle-class Jamaican nationalist movement's program of "self help through moderate middle-class leadership and the transformation of (lower class) people's cultural practices, without substantial reform of the larger political and economic context" (Thomas 2004:30). According to Thomas (2004:55), this narrow focus on culture over socioeconomic inequalities helps explain the "failure of anti-colonial nationalism to catalyze more egalitarian social relations" on the island and has led to declining faith in middle-class leadership over the past century, a situation which has weakened the government's ability to mobilize the population to address recent economic crisis.

Beyond the shores of the island, the vision of working-class "illegitimate" sexuality brought forth by birth control advocates in late-1930s Jamaica would also contribute to the construction of a growing regional discourse on the "pathological" West Indian family. Promoted by the 1945 West Indies Royal Commission report (which called for "an organized campaign against the social, moral and economic evils of promiscuity" [Reddock 1994:6]) and a 1946 study by Social Welfare Advisor Thomas Simey that rooted the region's problems in family "disorganization," this discourse would "set the agenda for discussion on the family for the next two decades" (Chamberlain 2002:189) and shape the direction of the rising academic field of Caribbean sociology (Barrow 1999:2-26). A series of studies on fertility in Jamaica funded by the American-based Conservation Foundation (Blake 1961; Roberts 1957; Stycos \& Back 1964) would also place Jamaica along- 
side Puerto Rico and other Latin American nations as a "classic" example of "dangerous" fertility in tropical areas (Roberts 1957:vii), 107 further enhancing the international panic over "overpopulation" cited by Jamaican birth control advocates in 1938. This scholarship would in turn be used to bolster both local and international calls for a government-led family planning program on the eve of independence in Jamaica.

The newly independent Jamaican government of 1962 would indeed identify the need for "the spread of information on and techniques for the spacing or limitation of families" as an integral part of their "Five-Year Plan," and by 1968 a massive campaign funded by state and international aid agencies had been launched in this direction (Brody 1981:12). But the work of spreading birth control to the working classes had begun decades earlier under the auspices of the Jamaican Birth Control League, an organization that continued to lobby the government and influential personalities throughout the 1940s-1960s, while also boldly taking the lead in distributing birth control to the working classes. Within a month of its formation, the League was publishing regular ads in the Daily Gleaner calling on working-class women to write in for information on birth control or make an appointment at the new clinic set up in Kingston in August 1939. ${ }^{108}$ Over the next few years, League secretary May Farquharson would indeed respond to over five hundred letters from women interested in applying this new technology to address their own diverse array of problems and concerns, defined according to their own understandings of family, morality, and prosperity. ${ }^{109}$ Many of these women would also visit the clinic, as well as another set up in the late 1950s by Dr. Lenworth and his wife Beth Jacobs, where they would receive and use reproductive technologies; some of them would also become test groups in the scholarly studies of fertility already mentioned. How Jamaican women and their partners would experience this attention and efforts to reform their reproductive lives as the island was transformed from a colony to an independent nation, however, remains to be fully explored.

107. These connections were primarily drawn by men such as J. Mayone Stycos and Kurt Back, who also did extensive work in Puerto Rico and South America (see Briggs 2002:117-20).

108. "Birth Control Clinic," Daily Gleaner, August 28, 1939, p. 5.

109. Jamaica Archives and Records Department, Kingston, May Farquharson Collection, $4 / 108 / 645$. 


\section{REFERENCES}

Ahluwalia, SAnjam, 2008. Reproductive Restraints: Birth Control in India, 18771947. Urbana: University of Illinois Press.

Austin-Broos, Diane J., 1997. Jamaica Genesis: Religion and the Politics of Moral Orders. Chicago: University of Chicago Press.

BArrow, Christine, 1999. Family in the Caribbean: Themes and Perspectives. Princeton NJ: Marcus Wiener.

BAXTER, IVy, 1970. The Arts of an Island: The Development of the Culture and of the Folk and Creative Arts in Jamaica 1494-1962 (Independence). Metuchen NJ: Scarecrow Press.

BESSON, JeAn, 2002. Martha Brae's Two Histories: European Expansion and Caribbean Culture-Building in Jamaica. Chapel Hill: University of North Carolina Press.

BLAKE, JUDITH, 1961. Family Structure in Jamaica: The Social Context of Reproduction. New York: Free Press of Glencoe.

Bolland, O. Nigel, 2001. The Politics of Labour in the British Caribbean: The Social Origins of Authoritarianism and Democracy in the Labour Movement. Kingston: Ian Randle.

BRIGGS, LAURA, 2002. Reproducing Empire: Race, Sex, Science, and U.S. Imperialism in Puerto Rico. Berkeley: University of California Press.

Brody, Eugene B., 1981. Sex, Contraception and Motherhood in Jamaica. Cambridge MA: Harvard University Press.

BRYAN, PATRICK E., 1990. Philanthropy and Social Welfare in Jamaica: An Historical Survey. Mona, Jamaica: Institute of Social and Economic Research, University of the West Indies.

-, 1991. The Jamaican People, 1880-1902: Race, Class and Social Control. London: Macmillan Caribbean.

Carnegie, James, 1973. Some Aspects of Jamaica's Politics, 1918-1938. Kingston: Institute of Jamaica.

CHAMBerlain, MARY, 2002. Small Worlds: Childhood and Empire. Journal of Family History 27(2):186-200.

GregG, Veronica MARIE (ed.), 2005. Caribbean Women: An Anthology of Non-Fiction Writing, 1890-1980. Notre Dame IN: University of Notre Dame Press.

HART, RICHARD, 1989. Rise and Organise: The Birth of the Workers and National Movements in Jamaica (1936-1939). London: Karia Press.

-, 1998. From Occupation to Independence: A Short History of the Peoples of the English-Speaking Caribbean Region. London: Pluto Press. 
—, 1999. Towards Decolonisation: Political, Labour and Economic Developments in Jamaica, 1938-1945. Kingston: Canoe Press.

Holt, Thomas C., 1992. The Problem of Freedom: Race, Labor, and Politics in Jamaica and Britain, 1832-1938. Baltimore MD: Johns Hopkins University Press.

MoORe, Brian L. \& MiChEle A. JohnSON, 2004. Neither Led Nor Driven: Contesting British Cultural Imperialism in Jamaica, 1865-1920. Mona, Jamaica: University of the West Indies Press.

POST, KEN, 1978. Arise Ye Starvelings: The Jamaican Labour Rebellion of 1938 and Its Aftermath. The Hague, the Netherlands: Martinus Nijhoff.

Reddock, Rhoda E., 1994. Women, Labor and Politics in Trinidad and Tobago: A History: “Brave Dange.” London: Zed Books.

Roberts, GeOrge W., 1957. The Population of Jamaica. Cambridge: Conservation Foundation at the University Press.

Soloway, Richard Allen, 1982. Birth Control and the Population Question in England, 1877-1930. Chapel Hill: University of North Carolina Press.

StePAn, NANCY LEYS, 1991. "The Hour of Eugenics": Race, Gender, and Nation in Latin America. Ithaca NY: Cornell University Press.

Stern, ALeXANDra MinNA, 2005. Eugenic Nation: Faults and Frontiers of Better Breeding in Modern America. Berkeley: University of California Press.

Stycos, J. MAYONE \& KURT W. BACK, 1964. The Control of Human Fertility in Jamaica. Ithaca NY: Cornell University Press.

Thomas, Deborah A., 2004. Modern Blackness: Nationalism, Globalization, and the Politics of Culture in Jamaica. Durham NC: Duke University Press.

THOYWELL-HENRY, L.D. (ed.), 1940. Who's Who and Why in Jamaica: 1939-1940. Kingston: Gleaner Company.

NiCOLE BOURBONNAIS

Department of History

University of Pittsburgh

Pittsburg PA 15260, U.S.A.

<nicbourbon@gmail.com> 